
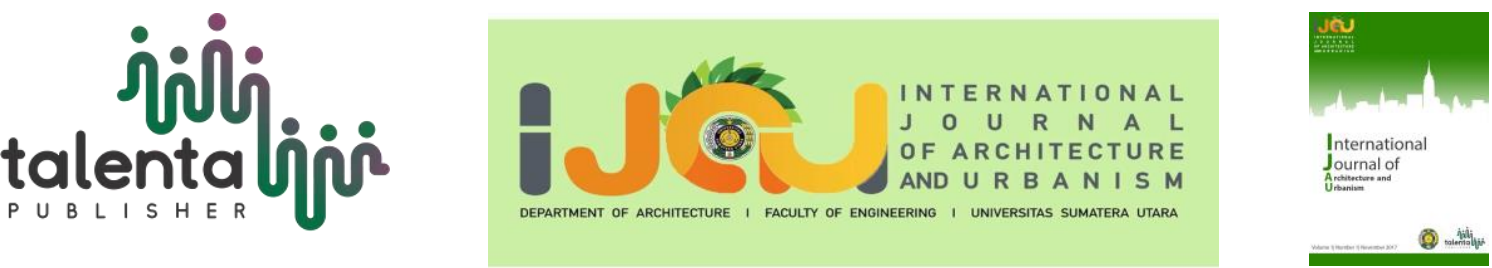

\title{
Evaluation of The Safety of Visitors To The Umbul Besuki Tour In Ponggok Village In Terms of The Construction of Facilities And Infrastructure
}

\author{
Dody Irnawan,ST.,MT ${ }^{1}$, Rizqiyah Safitri Juwito, ST.,M.Eng \\ ${ }^{I}$ Department of Architecture, Faculty of Civil Engineering and Planning, Universitas Surakarta \\ Karanganyar, Jawa Tengah, Indonesia \\ ${ }^{2}$ Department of Architecture, Faculty of Engineering, Universitas Bengkulu, Bengkulu, Indonesia
}

\begin{abstract}
Tourism cannot be separated from human life, because it is closely related to social and economic activities that can be enjoyed and is a way for humans to socialize. The city of Klaten is known to have many potential objects and tourist attractions that are able to attract tourists. This is what is then captured by tourism business actors to create new tourist objects and attractions that contain educational, creative, and attractive messages by taking the concept of nature. Umbul Besuki is a water recreation park in Ponggok Village Tourism, precisely in Kringan-Ponggok Hamlet. This area was developed as an unspoiled green area typical of a rural atmosphere. There were some visitors who were worried when swimming in the pool, for example slipping on the stairs, drowning because there was no sign of the depth of the pool, and falling from a temporary rest area. The importance of a material selection in planning a tourist attraction and complete safety support facilities, this is because many visitors of various ages. from the analysis and monitoring results, there are still many technical provisions that have not been considered, with the conclusion of the architectural design design.
\end{abstract}

Keyword: safety, Ponggok, pool, sweeming, construction

Received date 15 October 2021 | Revised 16 November 2021 | Accepted 17 November 2021

\section{Introduction}

Tourism cannot be separated from human life, because it is closely related to social and economic activities that can be enjoyed and is a way for humans to socialize. Local tourism is a regional potential. The potential for local tourism can be in the form of natural tourism, artificial tourism or special tourism. Each area that has various local or regional tourism potentials will be managed and developed to meet the needs of the community, both economically and non-economically.

\footnotetext{
*Corresponding author at: Department of Architecture, Faculty of Civil Engineering and Planning, Universitas Surakarta Karanganyar, Jawa Tengah, Indonesia

E-mail address: dody_ir@unsa.ac.id
}

Copyright (C) 2021 Published by Talenta Publisher, 
The city of Klaten is known to have many potential objects and tourist attractions that are able to attract tourists. This is what is then captured by tourism business actors to create new tourist objects and attractions that contain educational, creative, and attractive messages by taking the concept of nature. One of the sectors that can be utilized by rural communities is tourism, which later develops into tourism. special interest, namely the tourist village. Through the development of this tourist village, it is hoped that it can be an effort to empower local communities to be more advanced and independent.

Ponggok Village has tried to take advantage of the potential they have by turning their village into a tourist village by highlighting the natural beauty they have. Ponggok village has now been developed into a water tourism village, considering that Ponggok village has abundant water potential. In the village of Ponggok there are several sources of water or commonly referred to as "umbul" by local residents, namely Umbul Besuki, Umbul Sigedang, Umbul Ponggok, Umbul Kapilaler and Umbul Cokro. We can find each of these banners [1].

Umbul Besuki is a water recreation park in Ponggok Village Tourism, precisely in KringanPonggok Hamlet. This area was developed as an unspoiled green area typical of a rural atmosphere. Refreshing cold water, clean air is a source of life that must be maintained and preserved. There is Umbul Besuki spring which is a natural heritage, has a philosophy of water for life [2]. Umbul, which is now an ecotourism-based tourist destination, is planned for 2018 which begins with cleaning the river which is the flow path for the Umbul Besuki spring. Then in 2019, the springs were widened and at the same time made a public bathing area at Besuki Springs. At the end of 2019 the construction of facilities and infrastructure has reached $50 \%$ and until 2020 until now Umbul Besuki has become a tourist destination for several cities in Central Java [3].

Ponggok Village has natural wealth that can be developed so that there is a lot of tourism potential which is now very well known by the wider community. The Ponggok Village Government agreed to provide one banner (spring), namely the Umbul Ponggok to the Tirta Mandiri Village-owned Business Entity to be managed independently [4]. Within the scope of tourism sector,a business entity owned by Tirta Mandiri Umbul Ponggok indirectly becomes one of the assets of the village government that provides income to the village or adds to the village budget. One of the assets that is the responsibility of the Ponggok Village government of the many village assets it has. While the Besuki Umbul which is located in Hamlet Kringan, Ponggok Village is a banner that develops new rides for tourism. After Umbul Ponggok, now the Ponggok Village government is developing an underwater tourism vehicle that is not much different from the Umbul Ponggok ride. This tourist vehicle has the theme of adventure, education, and outbound arena. 
Community Based Tourism (CBT) is an alternative concept of tourism village management which is considered pro for the welfare of the local community, because management is fully within the power of the local community itself [5]. There are several things that often happen in the field, namely the lack of competence of human resources in tourist villages or they do not want to involve competent human resources. Thus, some facilities related to technical matters or standardization are not running well. It is not uncommon for accidents to occur in tourist areas, for example tourism based on water or nature rides. That it is necessary to pay attention to the safety factor of visitors, because various ages can enter the area. Such accidents include slipping, falling from a height, drowning and several other things.

Importance pay attention to the design and type of material that is in accordance with the safety standards for both adults and even more so for children, because the nature of children is play without regard to the risk of injury that will occur, then the principles of design and materials that are safe for children must be designed as early as possible [14].

The manager's attention to the safety aspect of tourists in tourist villages is a factor causing the lack of interest in visiting, even though one of the requirements for a good tourist village is the guarantee of safety and security. Safety assurance is the main factor that determines the growth and development of a tourist destination, and includes the value of excellence that will determine the quality of a tourist destination [6].

There are several tourist objects in Umbul Besuki, among others; Umbul bathing pool, swimming pool, playing in the river, outdoor restaurant, outbound, meeting hall, camping area and various rides for children's toys such as toy trains and painting. From some of these rides, it is necessary to pay attention to the safety factor of visitors, the swimming pool in Umbul Besuki, one of which is a tourist attraction that attracts the attention of visitors, especially for teenagers and some are adults. From research data conducted by interview and observation, there were some visitors who were worried when swimming in the pool, for example slipping on the stairs, drowning because there was no sign of the depth of the pool, and falling from a temporary rest area. The importance of a material selection in planning a tourist attraction and complete safety support facilities, this is because many visitors of various ages. However, there are several things that need to be studied in the tourism object, namely in terms of safety in terms of the material.

\section{Literatur Review}

Swimming in the pool is a sport or recreational activity that is much favored by the community, including children. At the age of children, most of the time is used to play. So not infrequently every weekend the swimming pool is filled with children's visitors. This is because the swimming pool can be used as a place for recreation for the community, especially children who like to play with water. Thus, there is a need for supervision from parents to their children in 
every activity in the swimming pool which aims to protect their children so that an accident does not occur. However, this supervision is not fully carried out by parents. There is a team of officers on duty as lifeguards for visitors. Not only lifeguards as a supporter of safety factors, there are also swimming pool facilities and infrastructure, as well as safety equipment equipment that needs to be considered.

Besides that, improving facilities and infrastructure in an effort to increase visitors in a tourist destination needs to be done through improved management so that visitors feel comfortable, safe and guaranteed their health. especially in the tourism sector which organizes attractions related to visitor safety. the challenge of tourism management is how to create a balance of human existence when in a tourist destination with the environment or tourism object in the tourist destination itself. Especially when tourism objects in a tourist destination are active, management must be directed to the safety and security of visitors [9].

The rapid growth of the tourism industry in Indonesia is a fairly complex challenge in providing a sense of comfort and security for tourists. The comfort and safety factor in a tourism area is an added value and an opportunity for tourists to visit. As meant by UNWTO (2004) that it is time for tourist destinations in developing countries to provide alternative travel with guaranteed safety and security for tourists while traveling [10].

Management of sustainable tourism destinations, management criteria include one of them, namely safety and security. Such as the existence of a system to monitor, prevent, inform, report and handle issues related to safety and security, including health, fire, food hygiene, electricity and public transportation. As one of the supporting evidences, namely the availability of warning signs, the availability of security posts at strategic points, safety instructions at strategic points, there is a crisis center and standards for handling implementation when an emergency vehicle occurs, the standard for handling routine simulations in an emergency condition, and there is a standard for handling routine simulations in emergency conditions [11].

The use of symbols and warning boards that have been made by the manager is intended to provide information, introduction to the environment also means providing new understanding or education to tourists. Educational efforts include: providing signposts, information boards, warnings, prohibition boards, and so on. The manager makes locality-based safety signs, this is in accordance with the CBT principle which emphasizes locality as a reference in building all elements of its tourism products [12].

Visual communication, a good sign system must be easy to see, easy to read, easy to understand and trustworthy. Making and placing the right sign system will make visitors satisfied and not get lost so as to save time and effort. In addition to the placement of the sign system must also pay attention to color. The sign system at a tourist location will be more visible if you use 
contrasting colors. A good sign system must meet 4 (four) criteria, namely 1) easy to see, 2) easy to read, 3) easy to understand, and 4) trustworthy [13].

Risk in general is anything that can happen to humans that is not expected to arise. All human activities will basically have risks even though these activities aim to achieve pleasure [7]. According to (Peraturan Menteri Kesehatan RI Nomor: 061/Menkes/Per/I/1991) [8], a swimming pool must meet environmental health requirements and swimming pool building construction Floors and walls in swimming pools must be strong, flat, light in color, easy to clean, and watertight. The floor in the swimming pool is white or light. Then the corners of the walls and bottom of the pool must be curved (conus). There is no direct connection between clean water and dirty water and the swimming pool drain hole is equipped with iron bars. Then the stairs and pool handrails are round, rust-resistant, and do not protrude. The floor at the edge of the pool must be impermeable to water and have a width of at least $1 \mathrm{~m}$ and not slippery. Have a signboard regarding the depth of the pool. If there is a diving/slide board, it must comply with applicable technical requirements and not endanger swimmers.

\section{Methodology}

The method used is a survey method where researchers directly conduct field surveys in the Umbul Besuki area by observing and measuring objects and functions of existing facilities. Then in the analysis with the existing literature, then an evaluation of the facilities and infrastructure contained in the Umbul Besuki area is carried out. The final result that will be obtained is a conclusion that will provide design input to pay attention to the safety factor of visitors.

The literature review obtained will be used as the basis for studies and discussions related to the Technical Standard approach in public swimming pool tourism buildings.Technical Standard Approach In public swimming pool tourism buildings under study will identify according to the standards applied by Peraturan Menteri Kesehatan RI Nomor: 061/Menkes/Per/I/1991 and Swimming Pools Guidance Note Sport England Amateur Swimming Association 2011.

\section{$4 \quad$ Result and Discussion}

One of the factors to overcome the risk of accidents that exist in tourist attractions is an information board containing warnings. However, the warning board on Umbul Besuki only displays an information board about Sapta Pesona and a map of Ponggok Village tourist destinations, meaning that this information only provides information on the whereabouts of visitors and provides additional information for other tourist attractions. The unavailability of detailed tourist layout information in Umbul Besuki poses the risk of unclear destinations and 
parents find it difficult to direct places that are safe for children. Information boards are an important part of a guide that is in a tourist place [15].

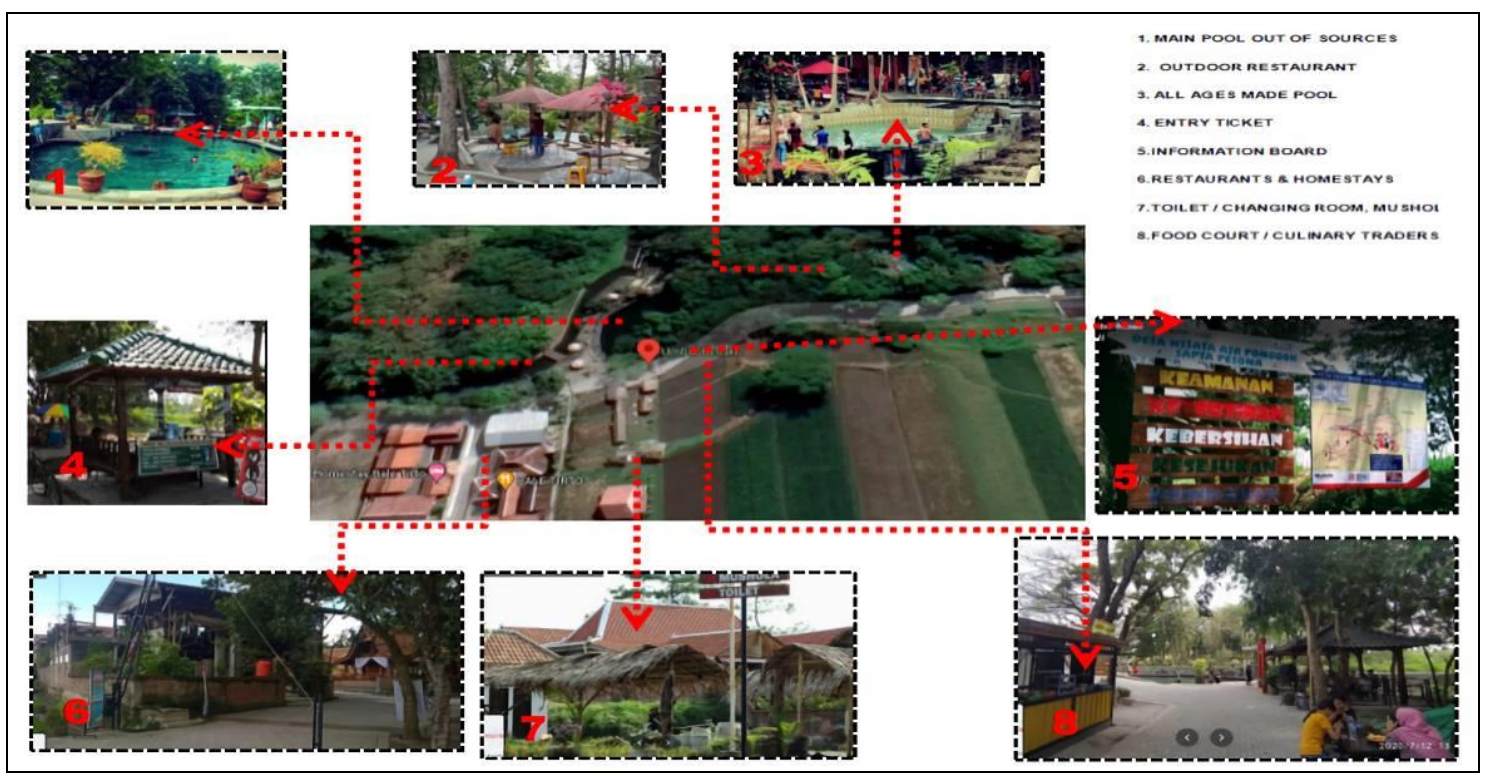

Figure 1. Various Tours In Umbul Besuki

When visitors arrive at Umbul Besuki, they can enjoy several tourist facilities as shown in Figure 1, starting from (1) an artificial pond whose bottom radiates directly from a natural spring; (2) There are also restaurants outside/nature; (3) artificial swimming pool rides for teenagers and adults; (4) Entrance ticket before entering the pennant besuki area; (5) an information board about the location of the Besuki banner in Ponggok village and information on Sapta Pesona Wisata; (6) There are restaurants and inns around the besuki banner; (7) Other facilities close to the swimming pool include a changing room, toilet and prayer room which are spacious and clean with views near the rice fields; (8) along the entrance to the pool there are food stalls and places to eat that are outside the area/nature.

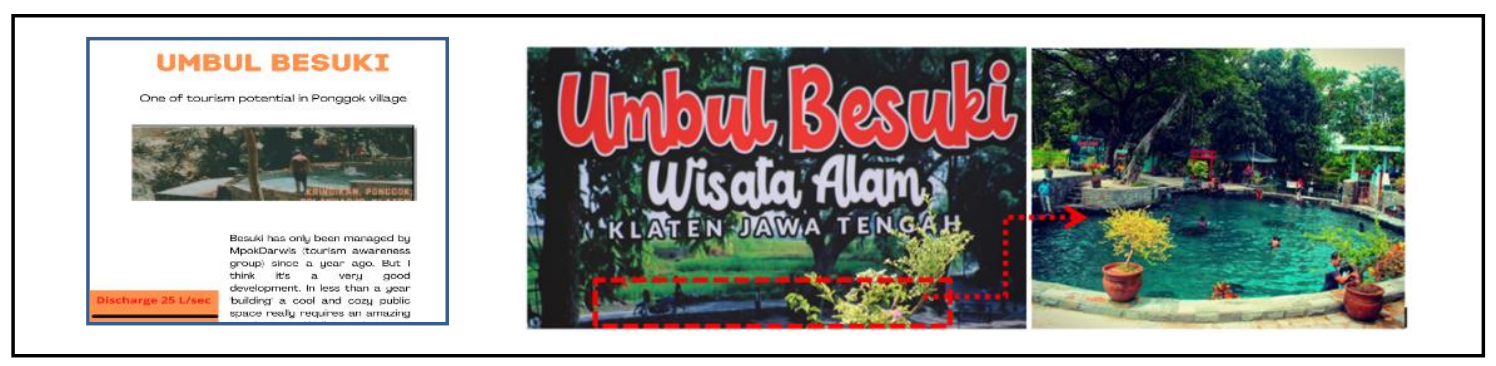

Figure 2. Information about umbul besuki on electronic media

Information about the umbul besuki banner on the electronic provides information about two rides that seem to be superior. In the Kompasiana media, which is shown in Figure 2 on the left with the title Umbul Besuki, One of the Potentials of Water Tourism in Ponggok Village is an artificial swimming pool contained in the Umbul Besuki banner. on the official website https://umbul-besuki.business.site/ which is shown in the picture in the middle provides an 
overview of the existence of the Umbul besuki pennant which shows the main pool whose water comes directly from the spring, namely the Umbul besuki pennant.

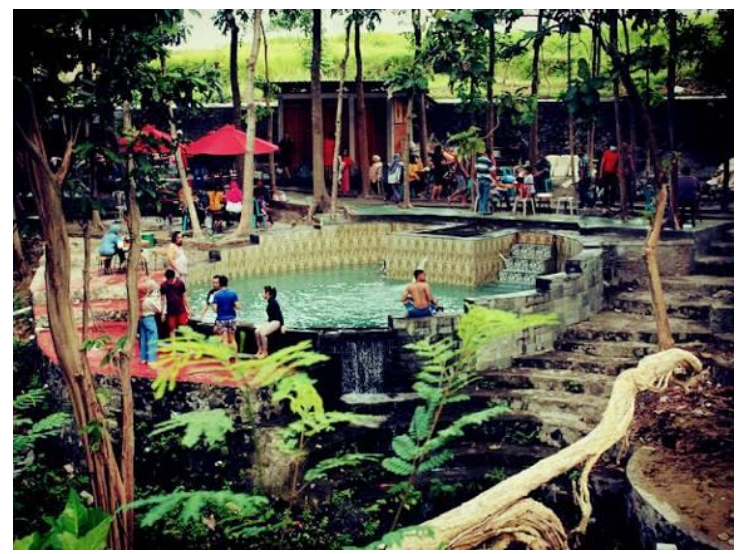

Figure 3. An artificial pool that is free to use for all ages

One object that is being targeted by children and adolescents is the medium-sized artificial pool shown in Figure 3 by showing the surrounding scenery surrounded by natural nuances. Researchers are interested in making observations around artificial ponds that are widely used by teenagers to adults but are very minimal with instructions or information related to safety standards and the risk of accidents.

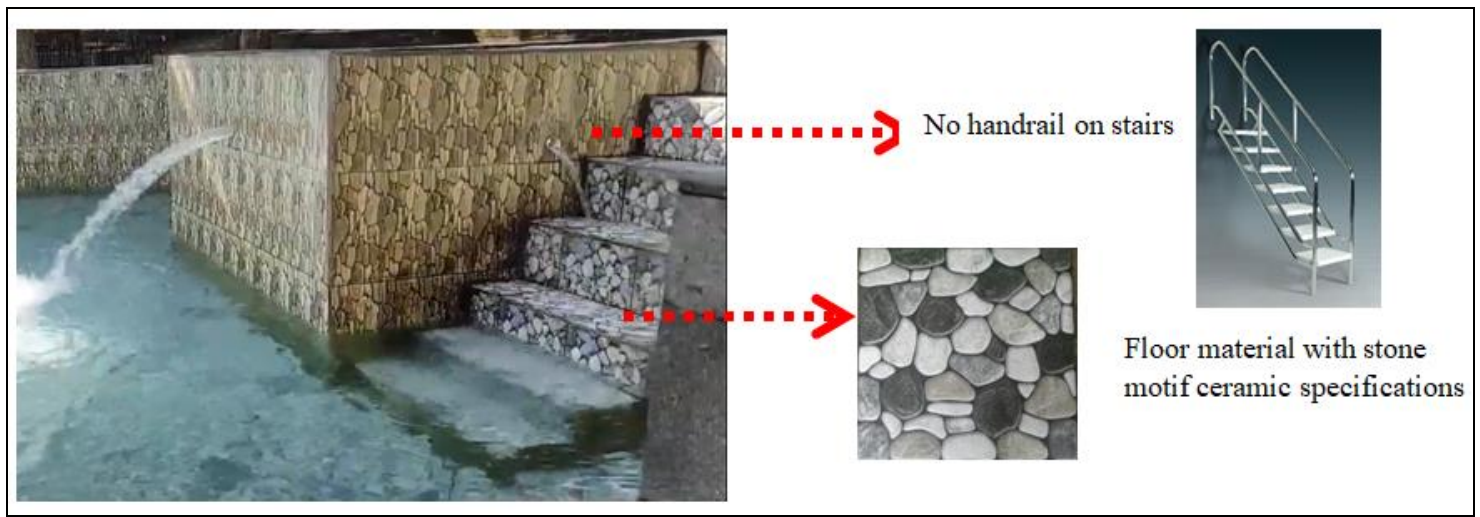

Figure 4. Types of Floor Materials and Staircase Accessories in swimming pools

It should be noted that the type of material and design in a pool must meet technical standards containing technical rules and safety rules for an object. Figure 4 shows that there are some parts of the swimming pool design and materials that do not meet technical standards. In the pool, the type of material The floor is made of ceramic with a slippery material. Then the pool stairs are also not equipped with banisters, this will be dangerous when someone wants to go down to the pool. In Swimming Pools According to the Sport England Swimming Pool Design Guidelines 2011 that the floor for the swimming pool must be specially made (not slippery) and on the stairs there must be handrails. 


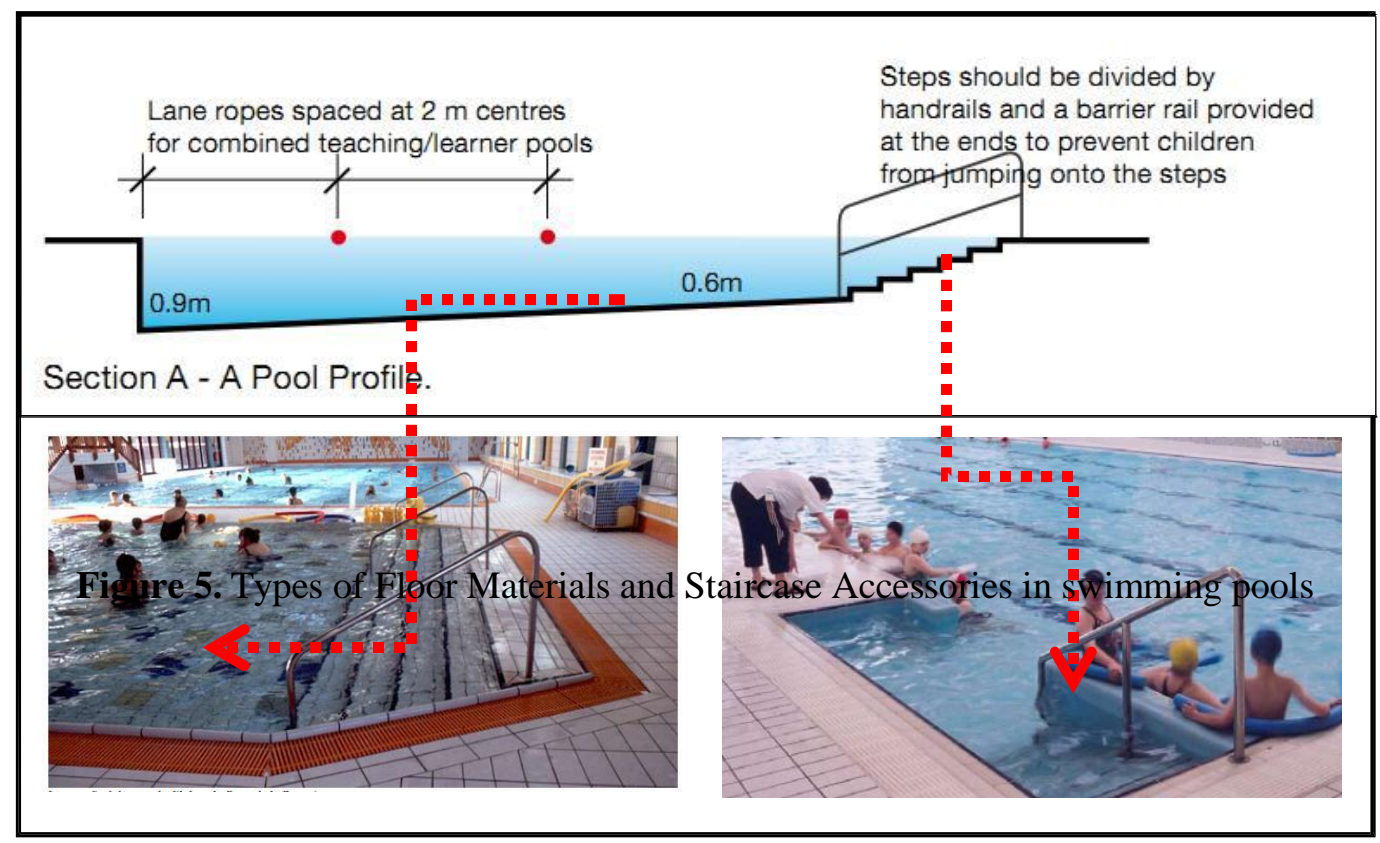

Recessed 'easy going' steps allow easy access to and from the water for all users shown in figure 5. ladders must be fully recessed. Steps should be positioned along the length of the pool rather than at the pool end and should be recessed within the pool surround. Steps should be gently graded with treads of not less than $0.3 \mathrm{~m}$ and risers of approximately $0.14 \mathrm{~m}$. There is a need for handrails to help children and ambulant disabled people walk down the steps into the pool. It is generally agreed that a deck level pool, with the water level the sameas the surround, has advantages. A hand grip for swimmers and an edge with a distinctive colour contrast should be provided.

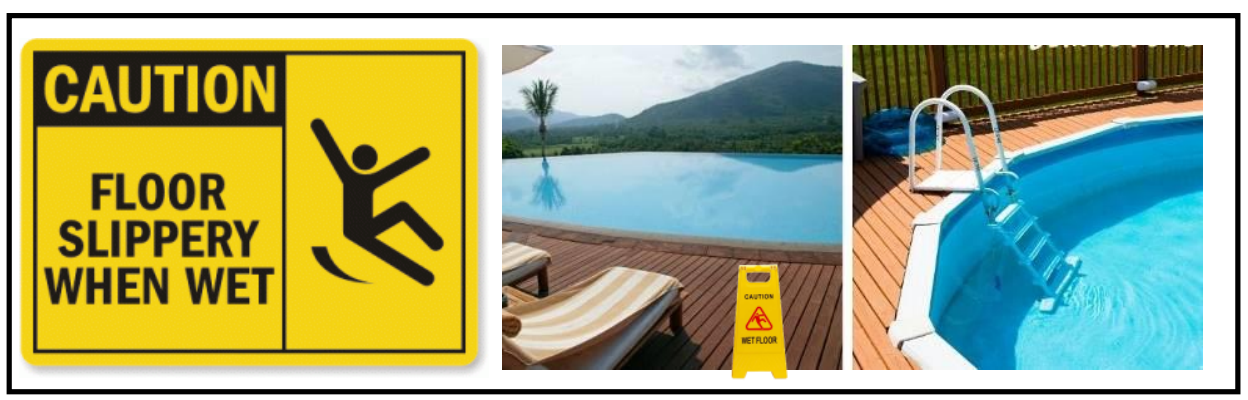

Figure 6. Types of Floor Materials and Staircase Accessories in swimming pools

Some swimming pools do not have a clear boundary between shallow and deep pools. It doesn't even give any information on how deep it is. In figure 6 there are people walking on the edge of the pool, it is very risky for visitors to fall into the outdoor area ofthe pool which is between $150 \mathrm{~cm}$ to $180 \mathrm{~cm}$ high. 


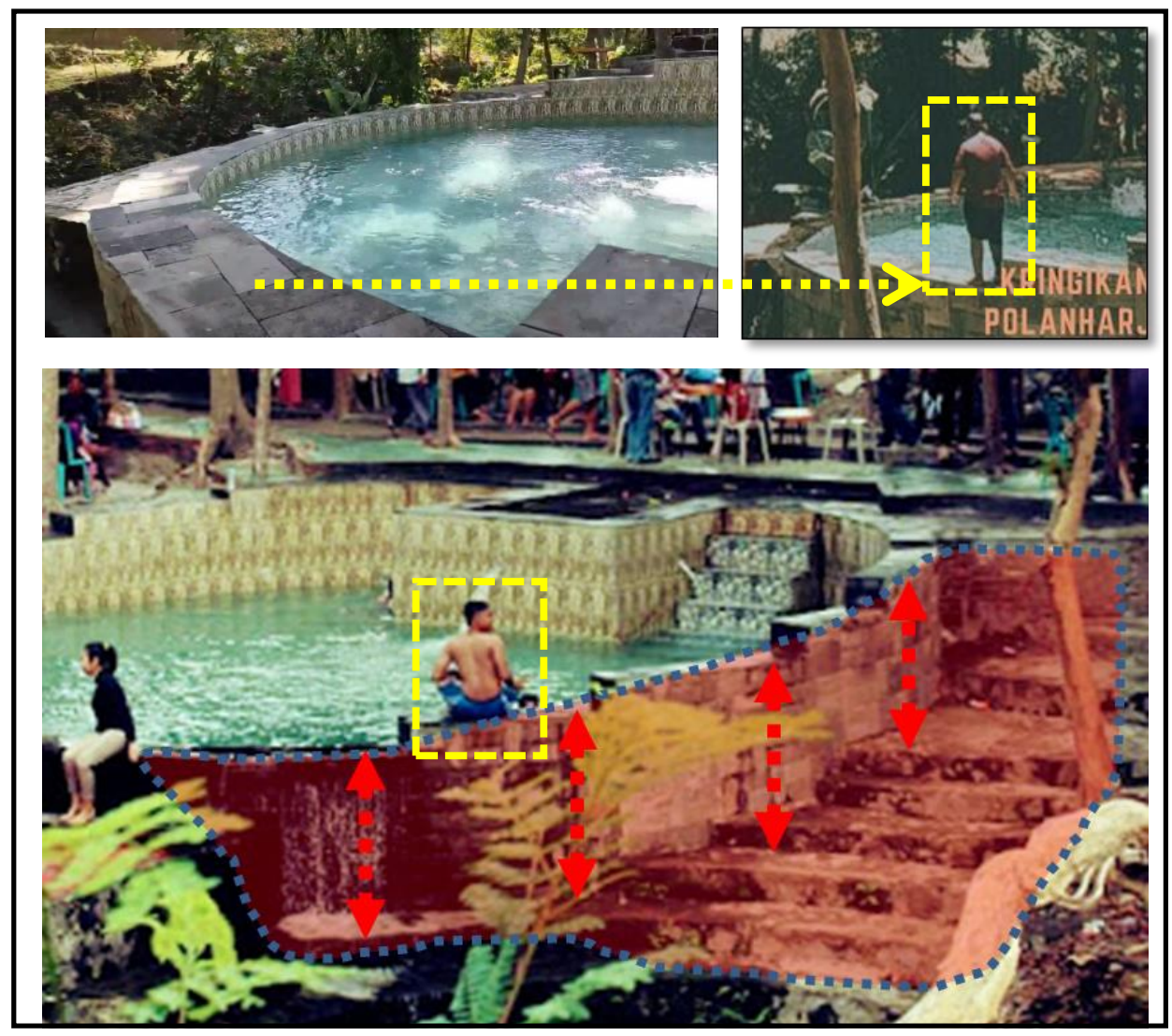

Figure 7. There are no water depth signs, fences and some warning signs

According to the Regulation of the Minister of Health of the Republic of Indonesia Number: 061/Menkes/Per/I/1991, swimming pools must meet the technical requirements of the swimming pool environment. Figure 7 shows a pool in the pennant seen from the overall view, there are several things that must be considered, such as the swimming pool floor must be strong, watertight, flat surface, not slippery and easy to clean. The floor at the edge of the pool must be watertight and have a width of at least 1 meter which is slippery, and the surface slopes out of the pool, because if the floor is used for roads as shown in picture (a), the risk of slipping is very high. In picture (b) it can be seen that visitors are sitting on the edge of the pool with a depth of $-+1.5 \mathrm{~m}$, this is very dangerous if they fall backwards. with a depth of $-+1.5 \mathrm{~m}$ as shown in figure (c) it is necessary to make a barrier to prevent visitors from falling backwards. 


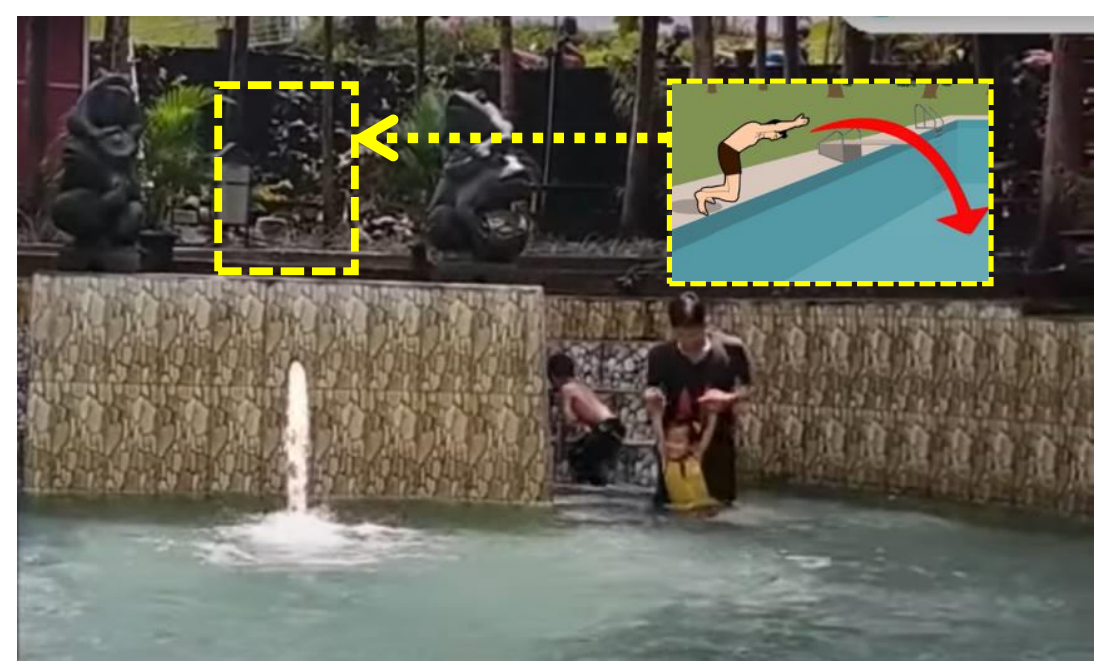

Figure 8. a place that is often used to dive

In each pool there must be a sign indicating the depth of the pool and a divider for those who can and cannot swim. It can be seen in Figure 8 that there are parents who invite their children to play in the pool, then in (a) it is often used to jump jump, even though to jump jump the pool must be marked with a predetermined depth. The need for a no-diving sign is often done by teenagers and even adults because the water depth is only 1.2 meters. Plunging means placing your head first in the pool. Therefore, the bottom of the swimming pool must be deep so as not to hit the bottom too quickly and risk injuring the head or spine. The Red Cross recommends 3 meters as a good level of depth for diving if you want to be extra careful, but the plunge area in most pools is 2.5 meters. If there are diving boards and skateboards must meet the technical requirements to prevent accidents.

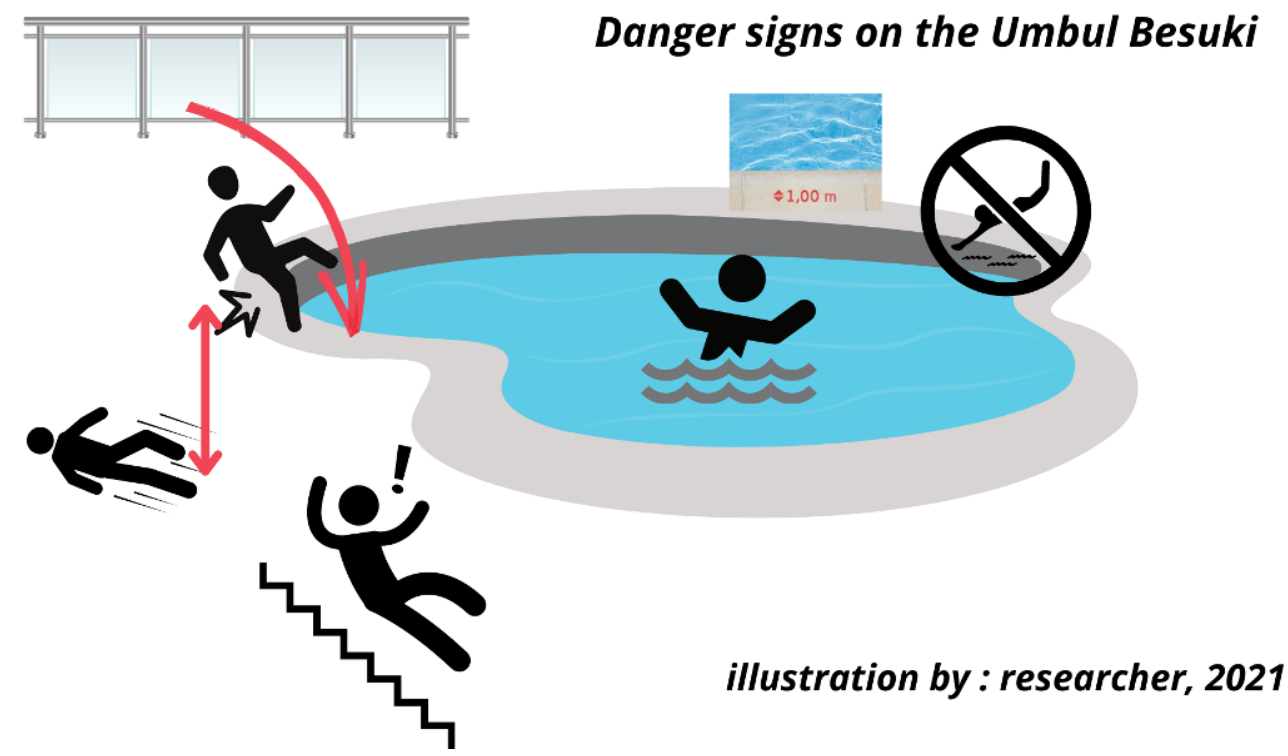

Figure 9. Illustration Of Danger Signs 
The need for a sign that shows the regulations that exist in a tourist pool, this aims to educate visitors who are mostly ordinary people and this has become a mandatory rule for every tourist pool. Figure 9 shows some signs that must exist in an artificial pond in the Umbul Besuki tourist attraction.

\section{Conclusions}

Researchers Provide alternative architectural designs to minimize the risk of accidents that often occur in tourist attractions, from the analysis and monitoring results, there are still many technical provisions that have not been considered, with the conclusion of the architectural design of course through signs and technical provisions on a tourist attraction will make it easier for tourist visitors to better educate through architectural language.

\section{Acknowledgment}

We would like to thank the Research and Community Service Institute (LPPM) for the Unsa Community Research Program which has supported this research to run well. Education and support from the faculty of civil engineering and planning at the University of Surakarta. We did this research solely to support the safety of child-friendly-based tourism and to support the advancement of ecotourism in Ponggok Village, Klaten.

\section{REFERENCES}

[1] E. N. Fatmawati, E. N. Satiti, and H. Wahyuningsih, "Pengembangan Potensi Desa Wisata Untuk Meningkatkan Kesejahteraan Masyarakat Desa Ponggok Kabupaten Klaten," 2017.

[2] umbul besuki, "No Title.” https://umbul-besuki.business.site.

[3] Desa Ponggok, Obrolan Nisa bersama Pengelola Umbul Besuki - Ngobrol Santuy. indonesia, 2020.

[4] RPJM Desa Ponggok. 2017.

[5] E. Darmawi, "Pengembangan Kepariwisataan Berbasis Masyarakat di Kota Bengkulu," J. Ilm. IDEA, vol. 4, 2010.

[6] Leong Choon Chiang, "Strategies for safety and security in tourism: a conceptual framework for the Singapore hotel industry," J. Tour. Stud., vol. 11, no. 2, pp. 44-52, 2000, [Online]. Available: https://search.informit.org/doi/10.3316/ielapa.200110920.

[7] I. Yudistira and A. Susanto, "Keselamatan Pengunjung Tempat Wisata," Widya, vol. 29, p. 320, 2012.

[8] Peraturan Menteri Kesehatan RI, Peraturan Menteri Kesehatan RI Nomor: 061/Menkes/Per/I/1991. .

[9] Suharto,"Studi Tentang Keamanan Dan Keselamatan Pengunjung Hubungannya Dengan Citra Destinasi (Studi Kasus Gembira Loka Zoo)," Jurnal Media Wisata, Volume 14, Nomor 1, Mei 2016. 
[10] Khalik. Wahyu," Kajian Kenyamanan dan Keamanan Wisata Di Kawasan Pariwisata Kuta Lombok. 2014

[11] Peraturan Menteri pariwisata RU, Nomor 14 Tahun 2016 Tentang Pedoman Destinasi Pariwisata Berkelanjutan

[12] Hermawan.Harry,"Kajian Desain Keselamatan berbasis Lokalitas Dalam Meningkatkan Kepuasan Wisatawan Terhadap Daya Tarik Wisata (Studi kasus Gunuung Api Purba di desa Wisata Ngelanggeran)," Jurnal Ilmiah pariwisata, Volume 22 No. 3 nopember 2017.

[13] Tinarbuko, Sumbo. 2012. Semiotika Komunikasi Visual. Yogyakarta : Jalasutra.

[14] Hendarti, Lely, and Dody Irnawan. "Tinjauan Bahan Material Ramah Anak Di Ruang Publik Kabupaten Grobogan Sebagai Penerapan Kota Layak Anak.” Jurnal Arsitektur Dan Perencanaan (JUARA) 2 (2). Universitas Aisyiyah (UNISA) Yogyakarta: 158-74. doi:10.31101/juara.v2i2.997.2019

[15] Cahyadin, Muhammad, et al. "Peran Media Informasi sebagai Sarana Penunjang Wisata Kolam Manggong Desa Batu Kumbung." Jurnal Pengabdian Magister Pendidikan IPA 4.1 (2021). 